\title{
Review of the National Style Research of Chinese Piano Solo Music in the 1980s
}

\author{
Hong Cheng, Shangfeng He \\ School of Music, Zhejiang Normal University, Jinhua, China \\ Email: 1604495791@qq.com
}

How to cite this paper: Cheng, $\mathrm{H}$. and $\mathrm{He}$, S.F. (2021) Review of the National Style Research of Chinese Piano Solo Music in the 1980s. Open Access Library Journal, 8: e8111.

https://doi.org/10.4236/oalib.1108211

Received: November 21, 2021

Accepted: December 18, 2021

Published: December 21, 2021

Copyright $\odot 2021$ by author(s) and Open Access Library Inc.

This work is licensed under the Creative

Commons Attribution International

License (CC BY 4.0).

http://creativecommons.org/licenses/by/4.0/

(c) (i) Open Access

\begin{abstract}
This paper takes the 1980s as the research horizon, with the Chinese piano solo national style as research, on the basis of collection, sorting, reading literature, chart to the 1980s Chinese piano solo national style research macro and dynamic theory, aims to promote their own understanding of Chinese piano solo national style problem, to lay a theoretical foundation for the future study of this subject.
\end{abstract}

\section{Subject Areas}

Art and Music

\section{Keywords}

1980s, Chinese Piano Solo, National Style

\section{Introduction}

The 1980s was an important turning point in the development of Chinese piano art. The creation of Chinese piano music developed towards "nationalization" and "diversification" [1]. The composers combined modern western composition with Chinese national music and composed a large number of new works with strong Chinese style. The piano adaptation of this period pays more attention to the new techniques and reflects the national sound effect. The composers combine folk tone and traditional functions and sound, making the piano work show a unique ethnic nature. The use of atonality, twelve sound systems and other techniques in the creation, also reflects the pioneering and innovative spirit of the composers. The creation of Chinese piano music and the embodiment of national style is the main line of the development of piano music in China. The study of national style in Chinese piano solo music can be expounded and 
understood from many angles.

The author found 124 studies on Chinese piano solo by searching the Internet, including 98 in academic journals and 26 papers. However, there are only 7 studies on the national style of Chinese piano solo, so it can be seen that the research on the national style of Chinese piano solo in the 1980s is of certain value. After reading and sorting out these documents and some books, I will analyze this issue from three perspectives: historical review of the 1980s, the development of Chinese piano solo and the embodiment of national style during the 1980s.

\section{A Historical Review of the 1980s}

In the 1980s, Chinese society began to transform into a far-reaching economic and social value, facing a more open and multi-meaningful social form. During this period, the trendy art developed to its peak during the "8th Five-Year Plan" period [2]. The social, economic and cultural arts of the 1980s made a qualitative leap in the social environment after the reform and opening up. Chinese piano music creation is a form of artistic expression characterized by polyphonic thinking. The practice of piano music creation in the 20th century reflects that its development is a process of continuous exploration and innovation.

A historical review of Chinese piano creation in the 1980s dates back to the early 10th century. The early 2 of 200 s was the beginning of Chinese piano music, during which Zhao Yuanren was a leading figure [3], marked by his Peace March. His song Oucheng is the first piano song with Chinese style. It depicts a vivid performance of folk art during the festival. Its music is dusty, Chinese and secularized. From then on, the musical instrument and piano with western characteristics has embarked on a road of sinicization. Xiao Youmei, who studied in Germany, has improved his piano works in their professional skills. He and Zhao Yuanren have created the creation of Chinese piano music. After the 1920s, domestic piano works began to emerge, among which the book New Dress created by Xiao Youmei is the first separately published piano song in China, the conscious pursuit of Chinese music style is also its main performance. Since then, one batch after another of composers have emerged in China, committed to creating piano works of Chinese national style [4]. In the 1930s and 1940s, it was represented by He Luting's Piccolo, in the 1950s and 1960s by Ding Shande's Suite, and in the 1960s and 1970s, by Mr. Wang Jianzhong in the 1970s [5].

Since the 1980s, composers have combined modern western composition with Chinese national music, and composed a large number of new works with a strong Chinese style. Such as Chu Wanghua's “Guess tune”, Luo Zhongrong's “Three Piano songs", Zhao Xiaosheng's “Tai Chi” and so on. The author mainly sorted out the three general directions: "breaking the mode of 'special period', bold innovation" [3], "developing and innovating national tone and tonality, pursuing the nationalization of works" [6], "inheriting the traditional Chinese 
culture and moving to a new road of personalized and independent creation" [7]. The piano adaptation of this period pays more attention to the new techniques to reflect the national sound effect. The composers combine folk tone and traditional functions and sound, making the piano work show a unique ethnic nature. The use of atonality, twelve-sound system and other techniques in the creation, but also reflects the pioneering and innovative spirit of the composers.

Overall, the social, economic and cultural arts of the 1980s made a qualitative leap in the social environment after the reform and opening up. This period was also a prolific era for composers, during which the cultural prosperity and opening to the outside world enriched composer composition techniques and improved professional skills [8]. The creation of piano works has entered a new stage of national art, and the composers began to create piano works in line with the Chinese aesthetic concepts and with a new Chinese piano style.

\section{The Development of Chinese Piano Solo Music during the Period}

During the 1980s, Chinese piano solo music was further developed, and the prosperity and development of Chinese piano music presented a new scene. During the period, the creation of Chinese piano solo songs reflected the combination of western modern spirit and the whole Chinese cultural tradition. Since the 1980s, the creation of Chinese piano music has developed towards "nationalization" and "diversification" [9]. The composers have combined modern western composition with Chinese national music, and composed a large number of new works with strong Chinese national style.

In the 1980s, the thinking and concept of Chinese piano solo music creation have changed greatly, and they have entered a new stage of development, and the style, genre and techniques of the creation have also been updated. In the structure of the main body echoes the creation techniques, and the unified national tone techniques are used, so that the theme can clearly express the Chinese national tone. The piano works in this period, combined with western composition techniques and the use of polyphonic techniques, are mainly reflected in the rich and diverse variety of rhythm and image comparison, and a large number of discordant courses are used, to deeply explore the tonality color. In terms of music structure, Chinese piano music is influenced by the Chinese culture and the single sound line of traditional music, and the structure is not particularly regular but more diversified [10]. In terms of rhythm, more attention should be paid to the rhythm of Chinese national folk music and the combination of national musical instrument performance methods and modern piano performance methods.

At present, the Chinese piano works can be divided into the adaptations based on the ancient songs or folk tunes and the original Chinese piano works, while the Chinese piano works in the 1980s all show the unique charm of the traditional Chinese music and aesthetics. In the 1980s, Chinese piano solo songs were 
still not widely inherited and were not spread enough. As the creators of the new era, they still need to work hard.

\section{The Embodiment of the National Style during the Period}

In the creation of solo Chinese piano songs in the 1980s, the composer emphasized enriching the national style of multi-part weaving of Chinese piano works by exploring the playing skills, timbre characteristics and unique charm of national instruments. The form of folk song and dance and folk customs complement each other. Through the multiple weaving characteristics of the piano and the various factors of the folk song and dance form, the folk depiction will be produced. The creation of Chinese piano music and the embodiment of national style is also the main line of the development of piano music in China.

As for the reflection of national style during this period, we can start with Wang Lisan's piano set Ta Shan Collection, the title of this song is modeling and lyrical, and connects music with poetry. Mr. Wang Lisan combined national elements with western music creation techniques, and adopted polytonal techniques to broaden the multi-acoustic composition techniques of the piano, highlighting the charm of national cultural elements. There are various differences in tone styles of music of different nationalities and regions. Wang Lisan uses the characteristics of folk tones in various ethnic areas to select representative tones in his creation, which sublimate the national color in the piano works [11]. It also enriches the national color of the overall music form by strengthening the chord structure of three tones and high stacks and applying the heavy tremor effect of guqin.

The style of music works depends on the application of musical elements, and the piano creates a new space for the excavation and application of national music elements. Piano weaving is of a national style and is very important [12]. Only by organically combining all levels of the weaving body and applying it in coordination, can we more accurately reflect the national style and express the ideological content of the works. The use of rhythm directly determines the basic character of the music. The composer emphasizes enriching the national style of multi-part weaving of Chinese piano works by digging into the playing skills, timbre characteristics and unique charm of Chinese piano instruments. The form of folk song and dance and folk customs complement each other. Through the multiple weaving characteristics of the piano and the various factors of the folk song and dance form, the folk depiction will be produced. For the player, the combination of "sound and painting unity" [13] and "meaning first" [14] can better define the purpose of the performance. The exploration of the national style of piano weaving is from simple to complex, from local to whole, from plane to three-dimensional, and from micro to macro, which will be further improved with the development of The Times. We should create and develop the Chinese piano music based on the national music culture, so as to show the national style of the Chinese piano works woven body. The music form full of re- 
gional and ethnic colors has become an important part of the construction of music culture. China has rich types of national music elements, such as national language, Musical Instruments, customs, tuning and other elements, which all help to highlight the national characteristics of the piano works, make the Chinese audience more willing to listen to them, and further promote the development of the piano art. As a player, in playing Chinese piano works, we should accurately grasp the artistic thinking of the creator, understand the intention of integrating national elements, deeply explore the ideological connotation of the work, highlight the emotional tendency of national piano music, and comprehensively understand the charm contained in the work and understand the artistic charm of national piano music. The so-called "national is the world". The development of Chinese piano art should be based on national music, draw nutrients from national music culture, and actively use national music elements, so as to show national feelings and national style through piano music works, and then find a foothold in the world music art.

In terms of content, Chinese piano music has work themes that show painting content, life pictures, customs and so on. Melodic, there are typical Oriental music characteristics of unbiased five tone, partial tone of five tone of six or seven tone, and minority music style. In harmony, there are two four degree five degree fold, three degree fold, etc. In the playing method, the most important thing is the clever use of a large number of effective decorative sound. The innovation of composition techniques should pay attention to the national style and the acceptance ability of the audience, treat the influential piano works in the history of Chinese music from a historical and objective perspective, strive to create high-quality Chinese piano music, and should pay attention to the creation of piano works [15].

It can be seen from the above analysis, in the 1980s Chinese piano solo national style is by imitating the traditional Chinese instrument timbre, sound, rhythm, etc., to explore Chinese characteristics, on the basis of the western traditional harmony to join Chinese national harmony factors, on the development technique and structure of traditional folk music, using the degeneration of Chinese traditional music, performance, structural characteristics of music and so on [16]. The Chinese piano works in the 1980s all show the unique charm of traditional Chinese music and aesthetics. Nationalization is an inevitable trend for the development of Chinese piano creation [17]. We should have the courage to innovate, learn from it and learn from it, combine nationality with modernity, and create more piano music works with national characteristics.

\section{Conclusion}

In the 1980s, the national style of Chinese piano solo music is obvious. Whether adapted from traditional music works or original music works, Chinese piano composers always adhere to the artistic road of national music. The nationality of Chinese piano music works is characterized by ethnic elements, mainly linear 
melody, song structure, scattered rhythm, color imitation, harmony texture and so on. Through the study of the national style of Chinese piano solo in this period, the author believes that this paper aims to understand the research achievements of this period, which are the efforts of a generation of composers. In the new era, we should pass on the pursuit of excellent traditional Chinese culture and the pious attitude of national faith. Under the background of The Times, we should continue the national creation journey, keep pace with The Times, constantly seek and explore the national music factors with Chinese characteristics, and integrate and apply them into the creative process of piano music. The author just made a relatively simple review here, because of the relatively shallow experience for the collation, and analysis of the literature is not particularly in-depth, but will continue to have an in-depth understanding, to lay a good foundation for the later learning.

\section{Conflicts of Interest}

The authors declare no conflicts of interest.

\section{References}

[1] Tian, Q. (1986) Linear Thinking of Chinese Music. Chinese Musicology, No. 4, 58-67.

[2] Ling, R. (1989) The Exploration of "Verve" (PART 1). Yuefu New Sound (Journal of Shenyang Conservatory of Music), No. 3, 3-7.

[3] Wei, T. (1992) Ding Shande's Piano Solo Style Characteristics and Creative Achievements. Central Conservatory of Music Report, No. 1, 75-79.

[4] Dai, P. (1989) Six Issues on National Style. Chinese Musicology, No. 4, 24-35.

[5] Wang, C. (1991) On Multi-Layer Structure of Music Tradition. Journal of Central Conservatory of Music, No. 1, 21-24.

[6] Li, J. (1995) The Appearance and Concealment of Musical Structural Techniques-The Concept of Structural Force in Chinese Traditional Music (Part 3). Journal of Central Conservatory of Music, No. 3, 31-41.

[7] Wei, T. (1997) Old Steed with Bright and Vigorous Hoof-Mr. Hong Interview. Piano Art, No. 5, 4.

[8] Dai, B. (1999) Artistic Characteristics of Five Chinese Piano Pieces Adapted from Traditional Music. Huang Zhong (Journal of Wuhan Conservatory of Music), No. 3, 95-100.

[9] Wei, T. (2001) On the Concept and Theoretical Research Overview of Chinese Piano Art. Piano Art, No. 2, 20-21.

[10] Dai, B. (2004) Generations Are Born. The Symbol of Chinese Traditional Culture-An Analysis of "Chinese Style" in Wang Lisan's Piano Song \#F Shang: Calligraphy and Music. Huang Zhong (Journal of Wuhan Conservatory of Music), No. 2, 34-40.

[11] Tan, L. (2015) On the Fusion and Application of Ethnic Elements in Chinese Piano Music works-Also on the Nationality of Chinese Piano Music Works. Music Writing, No. 4, 113-115.

[12] Guo, H. (2008) On the Innovation and Development of Nationalization Elements in 
Li Yinghai’s Music Works. Minzu University of China Science, Beijing.

[13] Wang, G.-J. (2011) Study on the Singing of Li Ying-Hai's Ancient Poetry Art Song “Three Tang Poems". Zhejiang Normal University, Jinhua.

[14] Zhang, W. (2011) A Preliminary Study on the Creation of Chinese Piano Solo from 1979 to 1989. Central Conservatory of Music, Beijing.

[15] Liang, X.W. (2016) Research on the Development of Chinese Piano Works in the 1980s. Hunan Normal University, Changsha.

[16] Wang, Q. (2019) Research on Two Chinese Piano Works Adapted from Pipa Works. Central China Normal University, Wuhan.

[17] Li, Y. (2020) Research on the Creation of Chinese Piano Trio in 1980s. Qufu Normal University, Qufu. 